\title{
Penerapan Model Personal System For Intruction Dalam Pembelajaran Aktivitas Melompat Guna Meningkatkan Kemandirian Siswa
}

\author{
*Rizqi Apriandi Ruhyan ${ }^{1}$, Yunyun Yudiana ${ }^{1}$ \\ ${ }^{1}$ Program Studi Pendidikan Guru Sekolah Dasar Pendidikan Jasmani, \\ Fakultas Pendidikan Olahraga dan Kesehatan, Universitas Pendidikan Indonesia \\ email : kikirizkyapriandi@gmail.com
}

\begin{abstract}
Abstrak
Tujuan penelitian ini adalah untuk mengetahui apakah model PSI (Personal System for Intruction) mampu meningkatkan kemandirian siswa dalam pembelajaran aktivitas melompat kelas V SDN Cikareo Kabupaten Cianjur. Metode penelitan yang digunakan dalam penelitian ini adalah metode penelitian tindakan kelas yang terdiri atas tahap perencanaan, pelaksanaan, observasi dan refleksi. Objek penelitian yaitu siswa kelas V SDN Cikareo Kabupaten Cianjur yang berjumalah 28 orang siswa yang terdiri dari 18 laki-laki dan 10 orang perempuan. Instrumen penelitian yang digunakan dalam penelitian ini adalah lembar observasi, catatan lapangan, dan dokumentasi. Hasil pengolahan data diperoleh kesimpulan bahwa dengan menggunakan model PSI (Personal System for Intruction) kemandirian siswa dalam pembelajaran aktivitas melompat meningkat di setiap siklusnya, baik siklus I, maupun siklus II, nilai rata-rata yang diperoleh pada siklus I tindakan I $55,58 \%$, tindakan II $65,40 \%$, dan mengalami peningkatan pada siklus selanjutnya yaitu pada siklus II tindakan I 73,88\%, tindakan II 80,80\%, sehingga dari data tersebut disimpulkan bahwa dengan diberikannya penerapan model PSI (Personal System for Intruction) kemandirian siswa dalam pembelajaran aktivitas melompat meningkat.
\end{abstract}

Kata kunci: Model Pembelajaran, PSI (Personal System for Intruction), Kemandirian Siswa.

*Rizqi Apriandi Ruhyan Baisyah adalah lulusan Program Studi PGSD Penjas, Departemen Pendidikan Olahraga, Fakultas Pendidikan Olahraga dan Kesehatan, Universitas Pendidikan Indonesia. 


\title{
Implementing Personal System For Instruction Model In Jumping Learning Activities For Improving Children Independency
}

\begin{abstract}
The purpose of this research is to prove the efficacy of PSI model in improving the independency competency of children in learning process. To make it occur, the researchers conducted one Classroom Action Research to a group of children of grade V of SDN (Public Primary School) Cikareo Kabupaten Cianjur, involving 28 children, consisting 18 male and 10 female pupils. To collect data, an observation guideline to be occupied, combined with field notes and documentation. Result of the data processing summarized the following findings: 1) the PSI model occupied in the jumping learning activities has improved the independency competency of the children, that can be monitored on every cycles of the action, with each average is $55.58 \%$ on Cycle 1 Action 1; $65.40 \%$ on Cycle 1 Action 2, $73.88 \%$ on Cycle 2 Actin 1, and $88.80 \%$ on Cycle 2 Action 2. It is concluded that the application of PSI learning model has improved the competency of children's independency when it is implemented through jumping learning activities.
\end{abstract}

Keyword : Personal System for Instruction, jumping learning activities, children independency

\section{PENDAHULUAN}

Pendidikan jasmani merupakan suatu proses pendidikan yang memanfaatkan aktivitas fisik (Mahendra, 2015) yang dilakukan secara sadar dan sistematik melalui berbagai kegiatan dalam rangka memperoleh kemampuan dan keterampilan jasmani, pertumbuhan, kecerdasan, emosional dan pembentukan watak . Dalam mengajar pendidikan jasmani, seorang guru harus dapat menyesuaikan materi ajar dengan situasi dan kondisi, juga dengan karakteristik siswa yang tentunya setiap siswa mempunyai kekhasan dalam bersikap. Dalam perkembangannya, ternyata dalam pembelajaran pendidikan jasmani banyak sekali berkembang model-model pembelajaran. Perkembangan tersebut tentu harus diikuti dengan pemahaman serta pengaplikasiannya, sehingga seorang guru dituntut untuk memiliki pengetahuan serta pemahaman yang baik 
mengenai model-model pembelajaran. Namun, pada kenyataanya masih banyak guru pendidikan jasmani yang kurang memahaminya. Padahal dengan menerapkan banyak model pembelajaran maka akan sangat mendukung terhadap terbentuknya pembelajaran yang dapat membuat siswa aktif, inovatif, kreatif, efektif, juga menyenangkan, sehingga tujuan pembelajaran pendidikan jasmani akan berjalan dengan baik dan tujuan pembelajaranpun akan tercapai.

Pendidikan jasmani memiliki peran yang penting dalam meningkatkan kebugaran jasmani dan mengandung nilai-nilai pendidikan kepada peserta didik antara lain : percara diri, apresiasi, harga diri, kooperatif, sportivitas, tanggung jawab, kompetitif dan budaya hidup sehat, serta merangsang pertumbuhan dan perkembangan jasmani secara menyeluruh yakni, kognitif, afektif, dan psikomotor. Sebagaimana yang telah di ungkapkan oleh Juliantine,dkk (2012, hlm. 6) : "pendidikan jasmani merupakan alat pendidik yang menggunakan aktivitas fisik dan olahraga sebagai media untuk mencapai tujuan-tujuan pendidikan."

Kemandirian merupakan salah satu aspek kepribadian yang sangat penting bagi individu. Seseorang dalam menjalani kehidupan ini tidak pernah lepas dari cobaan dan tantangan. Individu yang memiliki kemandirian tinggi relatif mampu menghadapi segala permasalahan karena individu yang mandiri tidak tergantung pada orang lain, selalu berusaha menghadapi dan memecahkan masalah yang ada. Menurut Steinberg dalam Nurhayati (2010, hlm 58) kata "mandiri" diambil dari dua istilah yang pengertiannya sejajar sering disejajarkan silih berganti, yaitu autonomy dan independence, karena perbedaan sangat tipis dari kedua 
istilah tersebut (mandiri) secara umum menunjukan pada kemampuan individu untuk menjalankan atau melakukan sendiri aktivitas hidup terlepas dari kontrol orang lain.

Model pembelajaran PSI (Personal System for Intruction) merupakan model yang menitikberatkan pada penguasaan dan perolehan siswa. Yang dimaksud dengan penguasaan adalah bahwa siswa harus menguasai terlebih dahulu tugas yang diberikan kemudian diberikan tugas berikutnya. Perolehan mengandung maksud bahwa fokus outcome yang diharapkan melalui penampilan siswa, salah satu dari aspek kognitif atau psikomotor.

Atletik merupakan salah satu aktivitas fisik yang dapat diperlombakan atau dipertandingkan dalam kegiatan jalan, lari, lempar, lompat. Istilah atletik berasal dari kata athlon atau athlum dari bahasa Yunani. Kedua makna tersebut mengandung makna: pertandingan, perlombaan atau perjuangan, Saputra (2001, hlm 1). Dalam kurikulum pendidikan jasmani sekolah dasar tahun (2006) dijelaskan bahwa atletik berada dalam ruang lingkup pertama. Seperti yang telah dijelaskan diatas bahwa atletik terdiri dari unsur-unsur gerak utama yang mendasari banyak cabang olahraga yaitu: lari, jalan, lompat, dan lempar. Berdasarkan uraian diatas penulis akan melakukan penelitian pada nomor lompat. Lompat adalah suatu gerakan mengangkat tubuh dari satu titik ke titik yang lain yang lebih jauh atau lebih tinggi dengan ancang-ancang lari cepat atau lambat dengan menumpu satu kaki dan mendarat dengan kaki atau anggota tubuh lainnya dengan keseimbangan yang baik. Adapun nomor lompat horisontal yaitu lompat jauh. Lompat jauh adalah nomor olahraga atletik lompat yang 
menuntut keterampilan melompat ke depan sejauh mungkin dengan satu kali tolakan Adi, dkk (2008, hlm 39) (Pathurohman \& Wibowo, 2017).

Peneliti tertarik menerapakan model pembelajaran PSI (Personal System for Intruction) untuk melakukan penelitian, karena model tersebut dapat menumbuhkan konsep diri siswa serta memberikan kesempatan untuk menampilkan suatu tugas gerak dalam aktivitas bermain yang diberikan oleh guru, artinya model yang dapat meningkatkan kemandirian siswa serta meningkatkan keterampilan bermain. Memiliki kemandirian yang tinggi adalah hal yang dibutuhkan siswa untuk dapat meraih sebuah kesuksesan selain itu juga rasa optimis dan usaha yang tidak kenal pantang menyerah.

\section{METODE}

Metode yang peneliti gunakan dalam penelitian ini adalah penelitian tindakan kelas (Class Action Research) sebagai cara untuk menjawab permasalahan dalam penelitian. Adapun peneliti menggunakan metode ini berdasarkan pada bentuk penelitian itu sendiri yang bertujuan untuk meneliti suatu peristiwa atau suatu masalah yang kemudian melihat apa penyebab dari timbulnya masalah atau peristiwa itu terjadi. Dimana manfaat yang dapat diambil dari Penelitian Tindakan Kelas adalah perbaikan praktis yang meliputi penanggulangan berbagai masalah yang telah dialami oleh siswa yang diajar oleh guru sebagai pelaku PTK. Subjek penelitian yaitu siswa kelas V SDN Cikareo Kabupaten Cianjur yang berjumalah 28 orang siswa yang terdiri dari 18 laki-laki dan 10 orang perempuan. Instrumen penelitian yang digunakan dalam penelitian ini adalah lembar observasi, catatan lapangan, dan dokumentasi. 


\section{HASIL DAN PEMBAHASAN}

Hasil penelitian untuk mengetahui peningkatan karakter kemandirian pada siswa. Nilai persentasi kemandirian belajar siswa pada observasi awal berada pada kriteria mulai terlihat dengan perolehan angka $47.32 \%$, pada siklus satu tindakan satu karakter kemandirian belajar siswa berada pada kriteria mulai berkembang dengan perolehan angka 55.58\%, begitu pula pada siklus satu tindakan kedua karakter kemandirian belajar siswa masih berada pada kriteria mulai berkembang dengan perolehan angka $65.40 \%$, sedangkan pada siklus dua tindakan satu karakter kemandirian belajar siswa masih berada pada kriteria mulai berkembang dengan perolehan angka $73.88 \%$, dan pada siklus dua tindakan dua karakter kemandirian siswa berada pada kriteria membudaya dengan perolehan angka $80.80 \%$. Dengan demikian penguatan karakter kemandirian belajar siswa pada siklus dua tindakan dua sudah sesuai dengan apa yang diharapkan.

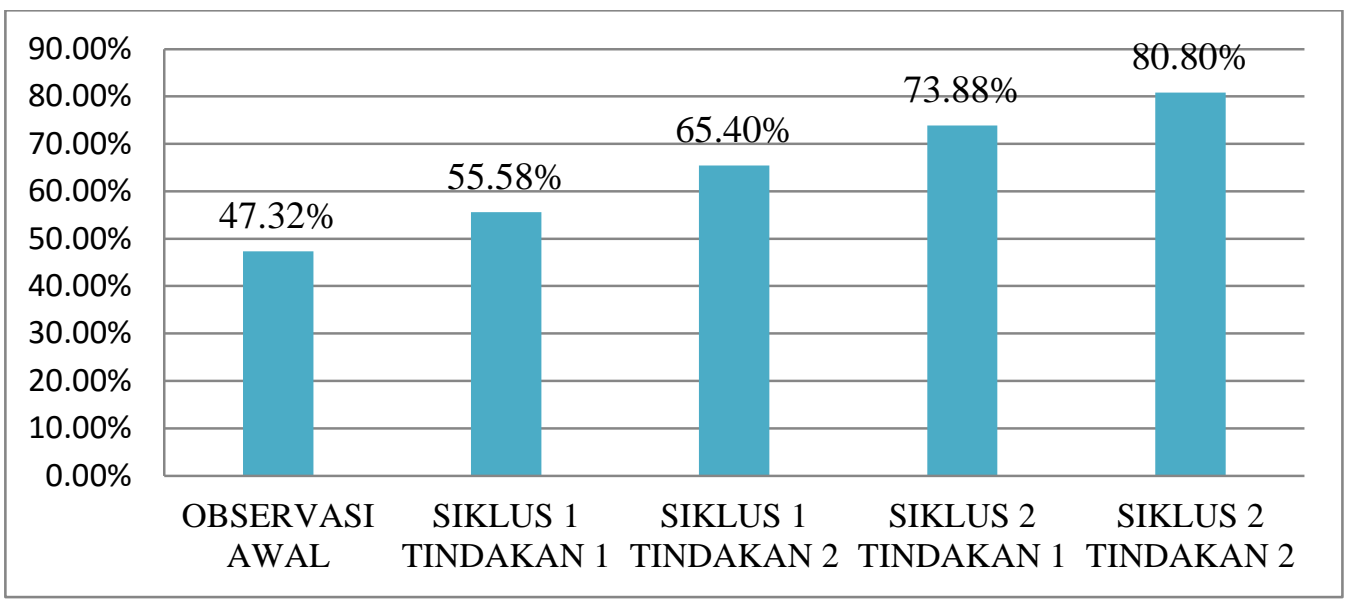

Grafik 1

Perolehan Nilai Persentase Karakter Kemandirian Siswa dalam Pembelajara Aktivitas Melompat Melalui Penerapan Model PSI dari Setiap Tindakan 


\section{KESIMPULAN}

Berdasarkan hasil dari penelitian tindakan kelas yang telah dilaksanakan di SDN Cikareo Kabupaten Cianjur, maka dapat disimpulkan bahwa penerapan model PSI (Personal System for Intruction) dalam pembelajaran aktivitas melompat mampu meningkatkan kemandirian belajar siswa kearah yang lebih baik. Hal ini dilihat dari peningkatan indikator-indikator kemandirian belajar siswa, yaitu peningkatan dalam indikator percaya diri, indikator disiplin, indikator inisiatif, dan indikator tanggung jawab. Peningkatan dalam proses pembelajaran tersebut terjadi secara bertahap yaitu dari tahap pratindakan atau observasi awal, siklus I, dan siklus II.

Untuk perolehan skor rata-rata persentase tiap indikator kemandirian belajar pada siklus 1 tindakan 1 dan tindakan 2, indikator percaya diri $64,29 \%$, indikator disiplin 66,96\%, indikator inisiatif $67,86 \%$, dan indikator tanggung jawab 62,50\%. Pada tahap tindakan siklus II, persentase tiap aspek mengalami peningkatan, rata-rata persentase tiap indikator kemandirian belajar pada siklus 2 tindakan 1 dan tindakan 2, indikator percaya diri 78,57\%, indikator disiplin $82,14 \%$, indikator inisiatif $82,14 \%$, dan indikator tanggung jawab $80,36 \%$. Serta peningkatan setiap siklusnya yaitu, observasi awal 47,32\%, siklus satu 65,40\%, dan siklus dua $80,80 \%$.

Dari data tersebut diperoleh fakta bahwa penerapan model pembelajaran yang tepat dapat membuat siswa lebih antusias, kreatif, dan percaya diri dalam mengikuti pembelajaran, hal tersebut dapat dilihat dari hasil penelitian diatas. Hasil tersebut diatas didapat dari pembelajaran aktivitas 
melompat dengan menerapkan model PSI (Personal System for Intruction), dimana pembelajaran dengan menerapkan model pendekatan PSI (Personal System for Intruction) dapat memperlihatkan indikatorindikator kemandirian belajar yaitu, percaya diri, disiplin, inisiatif, dan tanggung jawab. Hal ini menandakan bahwa pembelajaran berlangsung efektif banyak siswa yang sudah menunjukan sikap mandiri dalam kegiatan pembelajaran, meskipun masih ada beberapa siswa yang masih kurang terlibat dalam mengikuti pembelajaran. Hal tersebut dirasa wajar, karena subjek penelitian yakni kelas $\mathrm{V}$ memiliki karakteristik yang berbeda-beda. 


\section{DAFTAR PUSTAKA}

Abduljabar, B (2010). Landasan Ilmiah Pendidikan Intelektual dalam Pendidikan Jasmani. Bandung: Rizki Press.

Arikunto, S. Dkk. (2011). Penelitian Tindakan Kelas. Jakarta: PT. Bumi Aksara.

Asep. (2014). Perbandingan Model Personal System for Intruction dengan Model Pembelajaran Inquiri terhadap Kepercayaan Diri Siswa dan Keterampilan Bermain Futsal dalam Aktivitas Pembelajaran Futsal. (Skripsi). FPOK UPI : Tidak Diterbitkan

Pathurohman, M., \& Wibowo, R. (2017). MENINGKATKAN HASIL BELAJAR LOMPAT MELALUI PRACTICE, (1), 139-149.

Hendrayana. (2007). Modul Bermain Atletik. Bandung: FPOK UPI.

Juliantine, T. (2011). Model-Model Pembelajaran Pendidikan Jasmani. Bandung : FPOK, Universitas Pendidikan Indonesia.

Juliantine, T. dkk. (2012). Belajar dan Pembelajaran Penjas. Bandung: CV. Bintang Warli Artika.

Lestari, Utami Tri. (2016). Peningkatan Kemandirian Belajar Siswa Dengan Menggunakan Model Discovery Learning Dalam Pembelajaran IPS. (Skripsi). FPIPS UPI. Bandung: Tidak diterbitkan

Mahendra, A (2015) Filsafat Pendidikan Jasmani: Dasar-dasar Pembelajaran Penjas di Sekolah Dasar. Bandung: CV. Bintang WarliArtika.

Metzler. (2000). Instructional Models For Physical Education. Copyright. 2000 by Allyn \& Bacon. A Pearson Education Company Needham Heights, Massachustts 02194

Novianti, Anisha. (2014). Penerapan Modifikasi Pembelajaran Dalam Upaya Meningkatkan Hasil Belajar Gerak Dasar Lompat Jauh. (Skripsi). FPOK UPI, Bandung: Tidak diterbitkan

Sumiati. N. (2015). Penguatan Karakter Kemandirian Belajar Siswa Melalui Pembelajaran Berbasis Proyek. (Tesis). Sekolah Pasca Sarjana, Universitas Pendidikan Indonesia, Bandung: Tidak diterbitkan. 